\title{
Oncogene DBL
}

National Cancer Institute

\section{Source}

National Cancer Institute. Oncogene DBL. NCI Thesaurus. Code C18335.

Human oncogene DBL is a mutated form of the MCF.2 cell line derived transforming sequence (MCF2) gene, located at Xq27, which encodes 4 alternative variants of the proto-oncogene DBL protein. Activation of the DBL oncogene is generated by 5-prime recombination with chromosome 3pter-p21 and by 3-prime recombination with chromosome 16p13-q22. 